\title{
Beginning of Consolidation in Indian Banking Sector: Measuring Operating Feasibility against Standard Benchmark: a Case Study of HDFC Bank Acquisition of Centurion Bank of Punjab
}

http://doi.org/10.21272/fmir.3(1).5-17.2019

\author{
Manish Sharma \\ Dr., Associate Professor, Department of Business Administration, India \\ S.K. Shukla \\ Prof., Dean, Faculty of Commerce, University of Lucknow, Uttar Pradesh, India
}

\begin{abstract}
This paper examines the outcome of selection of inorganic mode of expansion by HDFC bank in its brown field investment of \$2.4 billion for acquiring Centurion Bank of Punjab in India. This work investigates the achievement of operating performance by HDFC Bank-CBoP deal, up to five-year post acquisition, against a benchmark established using the concept of Economic Value Added. This work is an attempt by author to have deeper investigation in Mergers \& Acquisitions deal. Mergers \& Acquisitions though used synonymously refers to two distinct facet of financing, management dealing \& strategy making with the intention of making capital investment decision that can help a corporation grows leap and bound and cut competition. Mergers may result in creation of new entity with some others cease to exist whereas in acquisitions both acquirer and acquired entity may co-exists. Mergers and Acquisitions though a century old mode of expansion of entities, adopted by corporate giants all over the world, the surge in these activities all over the globe during the last three decades owe its reasons first to urge of CEOs for survival and expansion through all ways and avenues to prove their calibre under global recession scenario. Moreover, reduction in cost to communicate across border and to transport goods throughout the world and spread of trade liberalization by government of almost all countries all over the world has been a major contributor for spurt in mergers and acquisitions activities. Many times, M\&A was done to smooth seasonal business fluctuations, sometimes to find requisite investment for firms sitting on large stack of idle cash and sometimes to hedge investment portfolios.
\end{abstract}

Trillions \& trillions of dollars worth of transactions happened during past decades which showed that M\&A remained popular activity for growth among corporations. Day by day, newer deals record for volume \& worth of dollars are being created. Evidences shows that out of such a large number of M\&A transaction only few have benefited the shareholders of acquiring companies and major accumulation of wealth occur to the shareholders of target companies. The shareholders of acquiring firms receive either small or zero or even negative returns from mergers. This author, firstly, established the threshold limit of performance and then evaluating the actual performance of the deal against the benchmark established. The excerpts of the paper belong to authors own work undertaken during his doctoral programme and is pioneer and proven research with establishment of new methodology for analyzing M\&A deals with entirely new financial angle. Positivist approach has been adopted to analyze the case. The deal resulted in the overall negative operating performance for HDFC Bank. The analysis shows HDFC Bank failed to achieve positive EVA and performance benchmark in five years (2007-2012) post merger rendering the acquisition of Centurion Bank of Punjab a bitter pill for HDFC Bank managers.

Keywords: economic value added, mergers and acquisitions, operating performance.

JEL Classification: G34, M1.

Cite as: Sharma M., Shukla S. K. (2019). Beginning of Consolidation in Indian Banking Sector: Measuring Operating Feasibility against Standard Benchmark: A Case Study of HDFC Bank Acquisition of Centurion Bank of Punjab. Financial Markets, Institutions and Risks, 3(1), 5-17. http://doi.org/10.21272/fmir.3(1).517.2019.

(C) The Authors, 2019. This article is published with open access at Sumy State University.

\section{Introduction}

1.1. Mergers and Acquisitions: Financial and Economic Perception. Today's era is completely different from the one that business world faced in earlier times. In past, the primary focus of the companies was to maximize their profit but now maximization of shareholders' wealth has become the main objective of the 
Financial Markets, Institutions and Risks, Volume 3, Issue 1, 2019

ISSN (online) - 2521-1242 ISSN (print) - 2521-1250

companies. Management must take decisions after thoroughly analyzing the impact of the decision on the company's share price and dividend that the shareholders would eventually receive.

Unlike steady but slow result oriented organic growth, M\&A (an inorganic mode) have become easiest mode to achieve objectives of the firms. Adoption of inorganic mode facilitates CEOs and in turn management of the company to create value for their shareholders by resorting to those policies which enhances the share's market price through increased synergy and achievement of cost benefits. M\&A are undertaken by companies to achieve strategic, tactical and financial objectives. It is undertaken to achieve the net economic advantage. M\&A results in synergies or value addition from the firms' joint capacity to eliminate duplicate functions, exploit economies of scale, raise larger amounts of capital \& share managerial expertise (Ravens craft and Scherer, 1987).

Corporations, worldwide, resorts to M\&A to restructure, realign and reorganize their functionalities to equip themselves to face tough times ahead or to move ahead in time to kill competition. Apart from liquidity, dividend decisions, financing decisions, M\&A are critical investment decisions a CEO makes for her firm. This path may include consolidation, amalgamation and absorption.

1.2. Background: M\&A as Growth Strategy. The merging of two companies into one is not a recent idea there were 'waves' ${ }^{[1]}$ of corporate mergers back in the 1920s, the 1960s and the 1980s (Fairburn and Kay 1989) $)^{[2]}$. The Merger movement is predominantly a U.S. dominant phenomenon, which has witnessed merger waves.

1.2.1. Merger Waves. Mergers activities have been classified by various authors into so called waves by clustering activities during various periods. All of the Great Merger Movement ${ }^{[3]}$ occurred when the economy experienced sustained high rate of growth and coincided with particular development in business environments. Firms are not motivated to make large investment outlays when business prospects are not favorable. When favorable business prospects are joined with changes in competitive conditions directly motivating a new business strategy, M\&A activities are stimulated resulting in formation of 'mergers waves. (See Table 1 below)

Table 1. Merger waves

\begin{tabular}{|c|c|c|}
\hline Name & Period & Facet \\
\hline First Wave & $1897-1905$ & Horizontal mergers \\
\hline Second Wave & $1916-1929$ & Vertical mergers \\
\hline Third Wave & $1965-1969$ & Diversified conglomerate mergers \\
\hline Fourth Wave & $1981-1989$ & Co generic mergers; Hostile takeovers; Corporate Raiding \\
\hline Fifth Wave & $1992-2000$ & Cross-border mergers \\
\hline Sixth Wave & $2003-2008$ & Shareholder Activism, Private Equity, LBO \\
\hline Seventh Wave* & 2008-Present & Survival, Sustainability, Success \\
\hline
\end{tabular}

Source: IMMA, *term coined by the author.

Period 1897-1905 is the period of First merger movement characterized by horizontal integration. The increase in merger activities during this period were motivated and boosted by expansion in operation, economies of scale and inbuilt counter competition mechanism.

The Second waves from 1916-1929 witnessed vertical integration during mergers and also began with an upturn in business activity in 1922. About $60 \%$ of the M\&A occurred in the fragmented food processing, chemicals and mining sectors (Salter and Weinhold, 1980, p 4). The motive behind such mergers was to achieve technical gains from integration and to avoid dependence on other firms for raw material.

Third wave from 1965-1969 involved diversification and most mergers activities happened in that period were conglomerate mergers.

In Fourth wave of M\&A activities ranging from 1981-1989 mostly hostile takeovers and corporate raid occurred. Period of 1981-82 was a period of cut-throat competition and recession was prevalent at that time. Divestiture became a substantial portion of acquisition activity during the fourth wave.

Fifth wave witnessed cross border mergers and acquisitions activities owing to macro trend of Globalization of industries deregulation of industrial sectors and also due to increasing trend of takeover bids. Sixth wave of M\&A from period 2000-2008was driven by increased shareholder participation in firms M\&A activities, 
involvement of private equity players and increased numbers of leveraged buyout activities by new dynamic breed of entrepreneurial talent.

1.2.2. Present Scenario of M\&A. Surge in the M\&A activities all over the globe during the last three decades owe its reasons to the urge of CEOs for survival and expansion through all ways and avenues to prove their caliber under global recession scenario. Moreover, reduction in cost to communicate across border and to transport goods throughout the world and spread of trade liberalization by government of almost all countries all over the world has been a major contributor for spurt in mergers and acquisitions activities.

Many times, M\&A was done to smooth seasonal business fluctuations, sometimes to find requisite investment for firms sitting on large stack of idle cash and sometimes to hedge investment portfolios. Evidences shows that out of such a large number of M\&A transaction only few have benefited the shareholders of acquiring companies and major accumulation of wealth occur to the shareholders of target companies. The shareholders of acquiring firms receive either small or zero or even negative returns from mergers.

"So many mergers fail to deliver what they promise that there should be a presumption of failure. The burden of proof should be on showing that anything really good is likely to come out of one."-Warren Hellman, former head of Lehman Brothers (1994).

\section{Aims and Objectives of Research}

2.1. Objectives of the Research. The current upswing in activity in the domestic market as well as in the global market laid emphasis on the fact that strong conceptual and technical skills are required for anyone working in the field of Mergers and acquisitions. Mergers and Acquisitions may generate tax gains; increases revenue and can reduce the cost of capital. Benefits are manifold; thus, it is necessary that one should have clear insight of the concept before making oneself involve in it. Based on the above discussion, following objectives for the research are formulated.

2.1.1. Primary Objective. To critically examine the outcome of selection of inorganic mode of expansion by HDFC bank in its brown field investment of \$2.4 billion for acquiring Centurion Bank of Punjab in India. This work investigates the achievement of operating performance by HDFC Bank-CBoP deal, up to five-year post acquisition, against a benchmark established using the concept of Economic Value Added.

3. Methodology of the Study. In order to conduct the research work, the Positivist approach is applied.

3.1. Research Strategy. The proposed work is based on Case Studies, which will aim to compare and analyze the efficiency and performance of a company after post M\&A with its pre-M\&A performances against a value set as standard.

3.2. Research Methods for Data Collection. The study is based on secondary information.

3.3. Tools of Data collection. The work plan has emphasized on collection of requisite information and data through the secondary sources. The data is collected from articles, conference speeches, journals, magazines, newspapers, published financial statements, reports of SEBI, official websites of companies etc.

\section{Literature Review}

Several researchers have tried to study the performances of acquiring firm post merger. The most popular forms of empirical studies are event studies, accounting studies, clinical studies and executive surveys.

M\&A activity's dramatic effects on the shareholders wealth raise the need for thorough assessment on the part of researchers and practitioners to check the validities of company's market value changes and to determine whether all market participants precisely foresee the long-term effect of M\&A on shareholders wealth. A study of 41 large acquisitions between 1979 and 1990 found a strikingly high correlation between the acquiring company's short-term stock returns and a present value measure of its first five years of postacquisition operating performance (M. Sirower and S. Francis).

Events studies or accounting studies point out the fact that these gains are either small or non-existent (Kumar 2009). Ball and Brown (1968) \& Fama (1969) introduced the methodology of event study that has become the preferred method when measuring performance induced by an event. Event studies conducted by researchers' measures the abnormal return to the shareholders during the period surrounding the announcement of M\&A. This abnormal return is essentially the difference between the raw returns which is simply the change in the share prices and the bench mark index like the one calculated by CAPM or S\&P 500 etc (Krishnamurthy and Vishwanath, 2008). These returns also tend to vary by the time horizon being studied. 
Financial Markets, Institutions and Risks, Volume 3, Issue 1, 2019

ISSN (online) - 2521-1242 ISSN (print) - 2521-1250

Studies of one year returns post merger by Jensen \& Ruback (1983) showed that returns averaged -5.5\%. Longer time frame studies by Magenheim \& Mueller (1987) concluded that 3 years post merger studies showed a $-16 \%$ return (Peck, Temple, 2002)

Studies on short term performance reveal that the target shareholders are clear winners. On surveying the performance of acquiring and target shareholders, it is seen that over a period of three days spanning from one day prior to one day post the announcement, the share performance of the target companies tend to show positive return consistently across decades as compare to the acquiring companies (Andrade, Mitchell, Stafford, 2001).

Studies relating to the stock market response to acquisitions during the 1980 and 1990s report a rough 65:35 split between adverse \& positive reactions to the acquirers. Studies of the most recent large M\&A transactions from 1994-1997 are yielding virtually the same results. It must also be noted that there have been studies conducted that shows that the post mergers performance largely depends on the industry or sector, the firm is operating in, economic environment, the firm is facing, and thus cannot be generalised (Mantravadi \& Reddy, 2008). Results may also vary by the characteristics of the acquiring company and the mode of financing the transaction. Loughran and Vijh (1997) show that cash financed mergers do better than stock financed ones. Rau and Vermaelen (1998) show that value acquirer outperforms the glamour ones.

Surjit, 2002 carried out an analysis of 20 merging firms to compare the pre \& post takeover performance by applying a set of eight financial ratios. He found that profitability and efficiency of merging companies declined in the post takeover period. Swaminathan (2002) studied the sample of five companies \& found that four of the five acquiring firms improved operating and financial synergies (measured through financial ratios). Arora (2003) examined the post merger performance of merged companies using the value-added metrics of corporate performance such as Economic Value Added (EVA), Market Value Added (MVA) and Return on Net-Worth (RONW).

The analysis conducted by means of analyzing the abnormal operating performance are divided into two groups; those using the earning-based measures and those using cash flow-based figures. Ravenscraft and Scherer (1987) used both approaches and concluded that when measuring the performance by use of accounting profitability a decline in wealth was detected whereas when the analysis was based on cash flow no decline was found which was also supported by Ghosh (2001).

Khemani (1991) states that there are multiple reasons, motives, economic forces and institutional factors that can be taken together or in isolation, which influence corporate decisions to engage in M\&As. It can be assumed that these reasons and motivations have enhanced corporate profitability as the ultimate, long-term objective. Another study shows that merger did not lead to excess profits for the acquiring firm (Pawaskar, 2001). Mantravedi and Reddy (2008) investigate Indian acquiring firms and found that there are minor variations in terms of impact on operating performance following mergers in different sectors of Indian industries.

\section{Limitation of Above Studies}

The following are limitations of the various studied mentioned above:

The studies have taken only mergers and leaving acquisitions in most cases. Absence of establishment of any standard for the measurement of post M\&A operating performance further limits these studies.

With this back drop, here an attempt has been made in this paper to address some of the above issues not taken up in previously conducted work, which are as follows-

$>$ The present work has studied acquisition of Centurion Bank of Punjab by HDFC Bank.

Established a standard EVA performance against which the post M\&A performance will be evaluated.

Measurement of performance through both operating and financial perspective.

\section{The Financial Model}

6.1. Introduction: Economic Value Added (EVA). A metric that not only helps in measuring company's true economic profit but is also a professedly recent innovation in the field of internal and external performance measurement is a trade-marked variant of residual income known as Economic Value-Added (EVA). 
Economic Value-Added estimates a particular type of economic profit, which states that in order to earn genuine profits, it is not only necessary for a company to earn sufficient profit to cover the firm's operating costs, but also to cover the cost of capital. A positive EVA indicates that value has been created for shareholders by the company, and a negative EVA signifies that value has been destroyed by the firm during the period of operation.

The concept of Economic Value Added or EVA is useful \& accurate for performance evaluation. It allows us to dissect a company's market value into its known and expectational components i.e. EVA improvement which facilitates measurement of future growth value of combined entity.

In true sense, acquirer bet on future expected performance of combined entity while keeping in mind the preexisting performances of individual concern and then afterward zeroed on the premium to be paid to the shareholder of the target firm. This entire process involves allocation of capital for the investment that has cost associated with it, sometimes referred as opportunity cost of funds. Moreover, stock prices of the firms involved in the process of M\&A reflects cumulative expectations of all the shareholders, current as well as prospective investors, about the future performance, so it is more important that cost of capital needs to be recovered sufficiently to preserve value.

6.2. Performance Improvement: Change in Economic Value Added ( $\triangle E V A)$. The requisite standard value needed to adjudge post acquisition performance must take into account the improvement in performance after discounting performance improvements already priced in pre-acquisition market values of security, of both the firms: the acquirer and the acquiree, independently. It is even more desirable to quantify the market expectations and to gets its reflection in current prices of stock while evaluating the success of M\&A for the shareholder of the acquiring firm. It is this market expectation that lays the foundation of performance standard value.

6.3. Devising a Model. In narrow sense, the market value of firm is the summation of its value of debt and its value of equity. Evaluating the success of M\&A, as already stated earlier, involves segregating the market value of firm into its realized i.e. known component and component incorporating future expectations.

It is a well-established fact and need to be noted here that only after recovering the cost of capital invested in shaping the acquisition, the acquirer can begin to reap benefits for their shareholders from M\&A activity. Another question will be whether the benefits they are reaping is the same or better than the benefits they are reaping before investing new capital. Answer to these questions, though in approximation, must be found before management actually proceeds with acquiring a target.

Modigliani \& Miller (MM) had proposed in their work that if free cash flow (FCF) accruing to the firm is discounted by taking weighted mean capital cost as base, the discounted or present value so arrived at will represent market value of firm.

Using the Modigliani \& Miller's formula for deriving the present value of firm from free cash flow, we get market value of firm as

Present Market Value of Firm $=\sum_{t=0}^{\infty} \frac{\left(\text { NOPAT }- \text { Investment }_{t}\right)}{(1+c)^{t+1}}$

Where: NOPAT: Net Operating Profit after Taxes at the end of the year; c: Cost of Capital to the firm for funds required for $M \& A$.

Investment here represents any new capital investment required to be made by the firm (in this case acquirer) at the end of the year, rendering benefits over longer period of time.

Value calculated from above though can render a reliable measure of the value of firm, use of free cash flow has its limitation as it fails to evaluate true operating performance of firm on annual basis.The reason to this, belong to the fact that the entire investment cost is charged in the year of investment itself instead of spreading it to over a period of its benefits.

It is a well-established fact and need to be noted here that only after recovering the cost of capital invested in shaping the acquisition, the acquirer can begin to reap benefits for their shareholders from M\&A activity.

By making an adjustment in the above formula and introducing the concept of economic value added instead of free cash flow, this limitation can be eliminated \& the value of the firm can be calculated in an effective manner. 
Financial Markets, Institutions and Risks, Volume 3, Issue 1, 2019

ISSN (online) - 2521-1242 ISSN (print) - 2521-1250

Economic Value Added is arrived at after deducting Effective Capital Cost (ECC) from NOPAT.

Economic Value Added = NOPAT - ECC

Effective Capital Cost (ECC)is arrived at as a product of Capital investment and Weighted Mean Capital Cost

Effective Capital Cost $=$ Capital Investment $*$ WACC

Mark L. Sirower, of the New York University, presented his article on New Frontiers in Mergers and Acquisitions Research' in a Symposium in 1997 at Academy of ManagementMeetings,Boston, MA and pointed out that if for a firm the initial capital invested is added to the discounted future economic value added ,we can equate it to the discounted future free cash flow and in turn to market value of firm. ${ }^{[4]}$

According to him as the discounted value of capital consumption \& capital cost for EVA can be equated to cost of initial investment for FCF, the discounted value of any newer investment is same in case of both Economic Value Added (EVA) \& Free Cash Flow (FCF).

In other words,

Market Value of Firm= Discounted Future EVA+ Initial Investment of Capital

Now, by utilizing the concept of Economic Value Added and segregating the firm's value (acquirer) into its present known component and component for future expectation involving growth element by using MM equation (1961,416, Eq12) work on Dividend Policy Growth and Valuation of Shares, Journal of Business, University of Chicago (Vol XXXIV, No. 4) in October $1961^{[5]}$

$$
\left.\mathrm{X}_{0} / \mathrm{p}+\sum_{\mathrm{t}=0}^{\infty} \mathrm{I}_{\mathrm{t}}[\mathrm{p} *(\mathrm{t})-\mathrm{p})\right] . /\left[\mathrm{p}(1+\mathrm{p})^{\mathrm{t}+1}\right] \ldots \ldots \ldots \ldots \ldots \ldots \ldots . . \text { Equation....A }
$$

Where:

$\mathbf{X}_{\mathbf{0}}$ :is uniform perpetual earning on the current asset base

$\mathbf{I}_{\mathbf{t}}:$ is the investment at the end of the year $\mathrm{t}$

$\mathbf{p}^{*}(\mathbf{t})$ :is the constant rate of return on $\mathbf{I}_{\mathbf{t}}$ and $\mathbf{p}$ is the cost of capital

O'Byrne (1996) has transformed above equation A given by MM, and derived a generalized form for obtaining Economic Value Added's known \& future expectional component as

Present Market Value $=$ Book Capital $_{\mathrm{t}=0}+\left(\right.$ NOPAT $-\mathrm{c}^{*}$ Capital $\left._{\mathrm{t}=-1}\right)+\Delta$ EVA of Firm Equation B i.e.

$$
M V_{0}=C a p_{0}+E V A_{0} / c+[(1+c) / c]^{*} \sum_{t=1}^{\infty} \Delta E V A_{t} /(1+c)^{t}
$$

c is the weighted average cost of capital (WACC) using long rerm treasury return, target's beta, and risk premium (if any).

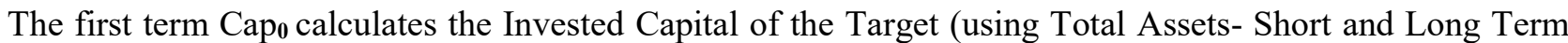
Non Interest bearing Liabilities-Deferred taxes+ Cumulative Amortization (for goodwill written off, if any). The second term Capitalizes the targets's cureent Economic Value Added at weighted average cost of capital (c). The first two term combined in above equation captures the known component of EVA or current operation value.

The third term will capture the growth in EVA or change in EVA i.e $\triangle$ EVA. This discounted value of expectational annual growth in EVA is also termed as Future Growth Value or FGV.

For any capital investment like M\&A, investors desires a return high enough to recapture cost of capital on current operation value as well as on future growth value $\&$ hence an adequate return of cost of capital on total market value is all what is actually desirable.This lays the very basis of standard performance against which any merger \& acquisition performance can be evaluated.

While focussing on achieving cost of capital return on FGV or expectational component of EVA or $\Delta$ EVA in today's competitive scenario, each and every company almost have positive change in their future growth 
value i.e. $\Delta \mathrm{FGV}>0$. But by taking an assumption of constant change in FGV i.e. $\Delta \mathrm{FGV}=0$, will simplify our model and is recommended to dimmune the complexity of calculations.

The consequence of this assumption, on acheiving a cost of capital return on an expected EVA improvement or FGV ,requires fulfillment of equation

$\mathrm{FGV}_{0} * \mathrm{c}=$ Change in $\mathrm{EVA}_{1}+$ Perpetual Value of $\mathrm{EVA}_{1}+$ Change in $\mathrm{FGV}_{1}$

Or,

$\mathrm{FGV}_{0} * \mathrm{c}=\Delta \mathrm{EVA}_{1}+\Delta \mathrm{EVA}_{1} / \mathrm{c}+\Delta \mathrm{FGV}_{1}$

On assuming constant $\mathrm{FGV}, \Delta \mathrm{FGV}_{1}=0 \mathrm{We}$ get,

$\mathrm{FGV}_{0} * \mathrm{c}=\Delta \mathrm{EVA}_{1}+\Delta \mathrm{EVA}_{1} / \mathrm{c}$

Equation $\mathrm{C}$

For any capital investment particularly, M\&A , having long term consequences, irrevocable, complex in nature and future centric, it is highly essential to assess the impact before proceeding to make the actual investment.

Right side of equation (C) depicts future expectational Economic Value Added in its current and perpetual form that contributes value not only to current FCF (free cash flow ) but also to current operational value in perpetuity. For a unit of money worth of EVA improvement there is a contribution of $(1+\mathrm{c}) / \mathrm{c}$ times to value.This can be explained as below using equation $\mathbf{C}$

$\mathrm{FGV}_{0} * \mathrm{c}=\Delta \mathrm{EVA}_{1}+\Delta \mathrm{EVA}_{1} / \mathrm{c}$ Equation C

Or

$\mathrm{FGV}_{0} * \mathrm{c}=\Delta \mathrm{EVA}_{1}(1+1 / \mathrm{c})$ or $\Delta \mathrm{EVA}_{1}(1+\mathrm{c}) / \mathrm{c} \ldots \ldots \ldots \ldots \ldots \ldots \ldots . . . . . . \ldots q u a t i o n ~ \mathrm{C} 1$

Or

$\Delta \mathrm{EVA}_{1}=\mathrm{FGV}_{0} *[\mathrm{c} * \mathrm{c}] /(1+\mathrm{c})$ Equation $\mathrm{C} 2$

In all, above equations provide that 1 unit money of EVA improvement add 1 unit money to current free cash flow \& perpetual value $1 / \mathrm{c}$ to current operation value which makes total contribution of each unit of money of $\triangle$ EVA to $(1+\mathrm{c}) / \mathrm{c}$ of value.

\subsection{Steps for Application of Methodology}

The basic steps required to evaluate the post acquisition performance of acquirer against our value based benchmark are listed below. These steps, though not exhaustive, are major stages for operating performance evaluation post merger \& acquisition which will mark the success of any deal.For evaluation of deal already happened, these variables are to be easily determined and available ready hand.

Step1: Determine the Pre-Acquisition Market Value of Target, without taking into consideration the Premium, if any, paid in the deal.

Step2: Determine the Market Capitalization of Target prior to the announcement of the Deal (Use Market Equity +Book Debt as value and take Five days prior period value before the deal is announced).

Step3: In the next step, calculate the Invested Capital of the Target (use Total Assets- Short- and Long-Term Non-Interest-bearing Liabilities-Deferred taxes+ Cumulative Amortization (for goodwill written off, if any)

Step4: Determine Weighted Average Cost of Capital (WACC) using Long Term Treasury Return, Target's Beta, and Risk Premium.

Step5: Next Step is to calculate Target's current NOPAT (Net Operating Profit after Tax) and EVA (Economic Value Added) using Target's prior year Opening Capital.

For calculation of NOPAT, add Net Income, Preferred Dividend,Minority Interst Income after -Tax Interest \& Amortization.

Step6: Capitalize the Target's current EVA obtained under Step 5 at WACC (obtained inStep 4)

Step7: In the next step, add Invested Capital (from Step 3 above) to the value of Capitalized EVA obtained in Step 6 to get Target's Current Operation Value. 
Financial Markets, Institutions and Risks, Volume 3, Issue 1, 2019

ISSN (online) - 2521-1242 ISSN (print) - 2521-1250

Step8: Last step with regards to calculations of variables of standalone Target is to obtain Target's Future Growth Value. For this deduct Current Operation Value of Target (from Step 7 above) from its Market Capitalization Value (from Step 2 above)

In our use of this methodology, as we discussed prior, the Target's Future Growth Value (FGV) obtained above in point 8 represents present value of expectational EVA improvement on which investors expects a cost of capital return along with a return on current operation value. In other words, the investors expect a cost of capital return on total market value. On multiplying the value obtained in Step 8 i.e. FGV with WACC (Weighted Average Cost of Capital from step 4) we get in money worth, the return on Target's expected future growth value (FGV).

In light of assumptions for application of this methodology discussed earlier, 1 unit of money worth of EVA improvement add $(1+\mathrm{c}) / \mathrm{c}$ of value et.al. At $\Delta \mathrm{FGV}=0$ (assume), the company need to achieve [Return on FGV /( 1+1/wacc)] of EVA improvement.

Premium paid by the acquirer is added to the future growth value of target. The effect of involvement of premium so paid, in the deal of M\&A, will affect the future growth value of target and also raise the return required on it. Conceptually, expected economic value-added improvement will also be raised. Our assumption of constant $\mathrm{FGV}$ or $\Delta \mathrm{FGV}=0$, results in to the fact that current operation value remain same unless any performance improvement happens and a constant return on FGV, thus, it in turn becomes the goodwill of the entity. In the last stage of performance evaluation, the standalone performance of acquirer is to be determined prior to the announcement of the deal. The value so determined will be used to combine it with the performance variables of the target (as standalone along with the premium paid, if any) in order to create the base period proforma.

This performance base year EVA obtained will be utilized to evaluate real post acquisition EVA improvements. The acquirer must achieve this post acquisition EVA improvement reflected in the proforma of the combined entity in order to earn an adequate return on cost of capital on its pre-deal market value in addition to a return on its investment to acquire the target.

Expected EVA improvements are compared with actual EVA improvements. The discounted or present value of the difference between these two is found out. The capitalized value of this discounted value would be the additional performance achieved in excess of the benchmark performance.

\subsection{Fine Points to be taken into Account while Implementing the Methodology}

- Use base capital for proforma entity as acquirer's book capital+ price paid for the purchase of the target while using purchase method.

- Use base capital as sum of acquirer's and target book capital in case of applying pooling accounting.

- Use sum of target and acquirer's NOPAT, one year prior to the date of acquisition to obtain NOPAT of the combine entity.

Capital cost of combined entity is the average of cost of capital of both target as well as acquirer by taking their market capitalization as weights. When a company involved in the deal is an unlisted one, then book value of capital employed of the company may be used as weight to calculate combinedweighted cost of capital.

\section{Parties to the Deal}

Housing Development Finance Corporation, a leading housing finance company in India, promoted India's premier bank HDFC bank. The bank was incorporated in 1994 and went public with its IPO in 1995. HDFC bank offers to its 11 million plus customers wide range of financial services in over 300 cities in India and also overseas with its NRI branches in Bahrain, Dubai and Hong Kong. HDFC bank is a leading player in retail banking, wholesale banking and treasury operations in India's banking industry.

Centurion Bank of Punjab (CBoP) was also a leading private bank in India and became even stronger after Lord Krishna Bank (LKB) merged with it in 2007. CBoP with its wide network of branches, atm network was offering individual customers service, dervices to small and medium enterprises and also to large Indian corporations. $\mathrm{CBoP}$ offered mutual fund, insurance, foreign exchange, agricultural loans, personal loans and whole lots of financial services to its Indian and NRI customers. CBoP was listed on Luxembourg Stock Exchange apart from Indian stoc exchanges. After merger of $\mathrm{LKB}$ with $\mathrm{CBoP}, \mathrm{CBoP}$ presence in sourthern 
Financial Markets, Institutions and Risks, Volume 3, Issue 1, 2019 ISSN (online) - 2521-1242 ISSN (print) - 2521-1250

part of India, especially in Kerala gets a big boost in terms of bank branches, network of atm and customer reach. CBoP had more than 394 bank branches, 452 ATMs and 7,500 employess working before its merger with HDFC bank.

In February 2008, boards of both the banks, CBoP and HDFC Bank met to discuss terms of merger of two in Rs 9510 crore deal and have decided upon share swap ratio of 1:29. Shareholders of CBoP would get 1 share of HDFC Bank of Rs.10 each for every 29 shares of CBoP of Rs. 1 each held by them. CBoP's share surge 14 percent to Rs.57 on the news of merger's announcement. The merger resulted in creation of India's second largest private sector bank, with name remain as HDFC Bank, having more than 1148 branches and with combined entity valuing nearly Rs.1500 billion. Earlier, HDFC Bank acquired Times Bank \& after acquisition of CBoP, HDFC Bank will be India's seventh largest commercial bank. HDFC shareholding in combined entity would be 19.20 percent, down from its earlier 23.28 percent in HDFC Bank. With hardly any overlap between CBoP and HDFC Bank in terms of operations and customer base, integration of two, after merger would be a smooth task for the management that also decided not to lay-off any employee after merger. The management of combined entity expected a growth of 40 percent in its business post merger and to step up its SME and retail business in Punjab, Haryana and Kerala where CBoP had strong foothold. Merger will also help HDFC Bank to penetrate rural areas.

To maintain the same level of holding of parent HDFC in it, HDFC Bank also planned for preferential allotment to HDFC in near future. In March 2009, RBI has also given its approval to the merger. Merger became effective from May 23, 2008.

\section{Analysis}

\subsection{Calculation for $\mathrm{CBoP}$ (standalone)}

Deal Value $=\$ 2.4 \mathrm{Bn}$

Deal premium $=21$ percent ( 1 share of HDFC at 1433 for 29 share of CBoP at Rs.41 per share)

\section{(a) For Centurion Bank of Punjab (CBoP) -}

Market Value ( Debt +Equity ) $=\$ 4.12 \mathrm{Bn}$

Treasury Yield $(\mathrm{Rf})=7.17 \%$

Risk Premium (Rm- Rf)= 6.83

Beta $=0.9917$

$\mathrm{WACC}=6.0778 \%$

Capital Employed one year prior $(2006)=\$ 2.28 B n$

(b) $\quad E V A$ of $C B o P(2007)=N O P A T-\left(W A C C^{*}\right.$ Capital $\left._{-1}\right)=\$ 0.04341 \mathrm{Bn}-(0.060778 * \$ 2.28 \mathrm{Bn})$

(c) Current Operation Value of $C B o P(2007)=(E V A / c)+$ Capital $_{0}=-\$ 0.111 B n / 0.060778+\$ 3.92 B n=$ $\$ 2.09 B n$

Applying, .. Equation $B$

Market Value $=$ Current Operation Value $+P V$ of Expected $E V A$ Improvement

Market Value $=$ Capital $_{0}+$ Capitalized $E V A(E V A / c)+P V$ of Expected $E V A$ Improv.

$\$ 4.12 \mathrm{Bn}=\$ 3.92 \mathrm{Bn}+(-\$ 1.826 \mathrm{Bn})+\mathrm{PV}$ of Expected EVA Improvement. Therefore, PV of Expected EVA Improvement $=\$ 2.03$ BnInvestors expects return on Market Value of $\$ 4.12 \mathrm{Bn}$ at WACC 0.060778 i.e. $(\$ 4.12 \mathrm{Bn} * 0.060778)=\$ 0.2504 \mathrm{Bn}$ of which $(\$ 2.03 \mathrm{Bn} * 0.06778)=\$ 0.138 \mathrm{Bn}$ represents expected return on $\mathrm{CBoP}$ future growth value.

Assuming $\triangle \mathrm{FGV}=0$, to provide return of $\$ 0.138 \mathrm{Bn}$ or $\$ 138$ million on CBoP future growth value, the company need to acheive, $\$ 0.138 \mathrm{Bn} / \$ 17.5=\$ 0.008 \mathrm{Bn}$ or $\$ 8$ million of $\Delta \mathrm{EVA}$ improvement in perpetuity as each $\$ 1$ of EVA improvement contribute $\$ 17.5$ of value. (using $\$ 1+\$ 1 / 0.060778=\$ 17.5$ - from Equation $\mathrm{C}$ )

\section{(2) Effect of Premium paid}

Effect of paying premium (approx. 21 percent in this deal) would result in enhancement of future growth value of $\mathrm{CBoP}(\$ 2.03 \mathrm{Bn})$ by amount of premium i.e. $\$ 2.03 \mathrm{Bn}+\$ 0.504 \mathrm{Bn}=\$ 2.534 \mathrm{Bn}$. So, Future Growth Value 
Financial Markets, Institutions and Risks, Volume 3, Issue 1, 2019

ISSN (online) - 2521-1242 ISSN (print) - 2521-1250

of CBoP would be $(\$ 2.534 \mathrm{Bn} * 0.60778)=\$ 0.172 \mathrm{Bn}$ as against $\$ 0.138 \mathrm{Bn}$ computed above $\&$ correspondingly Expected EVA improvement required would also be enhanced. Therefore, using $(\$ 0.172 \mathrm{Bn} / \$ 17.5)=$ $\$ 0.010 \mathrm{Bn}$ or $\$ 10$ million annual expected EVA improvement is required to provide cost of capital return on $\$ 2.534 \mathrm{FGV}$.

\section{(3) HDFC Bank standalone}

\section{(a) For HDFC Bank (2007)-}

Market Value ( Debt +Equity ) $=\$ 26.31 \mathrm{Bn}$

Treasury Yield $\left(\mathrm{R}_{\mathrm{f}}\right)-5 \mathrm{YR}=7.17$

Cost of Debt after tax $=4.90 \%$

Cost of Equity $=13.94 \%$

Risk Premium $\left(\mathrm{R}_{\mathrm{m}}-\mathrm{R}_{\mathrm{f}}\right)=6.83$

Beta $=0.9917$

$\mathrm{WACC}=6.0778$

Capital Employed one year prior $(2006)=\$ 14.2 \mathrm{Bn}$

(b) EVA of HDFC Bank $(2007)=$ NOPAT- $\left(\right.$ WACC $*$ Capital $\left._{-1}\right)=\$ 1.04 B n-(0.060778 * \$ 14.2 B n)=$ $\$ 0.1789 \mathrm{Bn} \mathrm{C} 2$

(c) Current Operation Value of HDFC Bank $(2007)=(\mathrm{EVA} / \mathrm{c})+$ Capital $_{0}=-\$ 0.1789 \mathrm{Bn} / 0.060778+$ $\$ 18.2 \mathrm{Bn}=\$ 2.94 \mathrm{Bn}+18.2 \mathrm{Bn}=\$ 21.14 \mathrm{Bn}$

Applying, .. Equation B

Market Value $=$ Current Operation Value + PV of Expected EVA Improvement

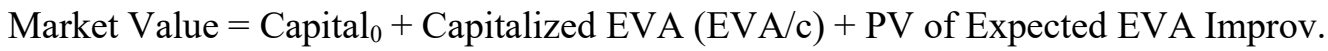

$\$ 26.31 \mathrm{Bn}=\$ 18.2 \mathrm{Bn}+\$ 2.94 \mathrm{Bn}+\mathrm{PV}$ of Expected EVA Improvement. Therefore, PV of Expected EVA Improvement $=\$ 5.17 \mathrm{Bn}$

\section{(4) HDFC Bank (Combined)}

(a) Market Value of HDFC Bank (combined) = Market Value HDFC Bank (standalone)+ Market Value of CBoP +Acquisition premium

M.V. of HDFC BankMV $\mathbf{c o m b i n e d}=\$ 26.31 \mathrm{Bn}+\$ 4.12 \mathrm{Bn}+\$ 0.504 \mathrm{Bn}$

$\mathbf{M V}_{\text {combined }}=\$ 30.934 \mathrm{Bn} \sim \$ 30.9 \mathrm{Bn}$

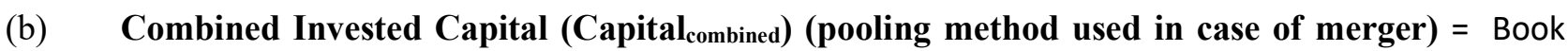
Capital of HDFC Bank (2007)+ Book Capital of CBoP (2007) $=\$ 18.2 \mathrm{Bn}+\$ 3.92 \mathrm{Bn}$ orCapital $_{\text {combined }}=$ $\$ 22.12 \mathrm{Bn}$

(c) NOPAT of HDFC Bank combined- $\left(\right.$ NOPAT combined $_{\text {) }}=$ NOPAT $_{0}$ of HDFC Bank (standalone) + NOPAT of $\mathrm{CBoP}_{0}=\$ 1.04 \mathrm{Bn}+\$ 0.04341 \mathrm{Bn}$ or NOPATcombined $=\$ 1.083 \mathrm{Bn}$

(d) WACC of HDFC Bank (combined) (by market cap. of two) $=0.06076$

(5) Calculation of Post Deal EVA \& EVA improvement of combined entity

(a) EVA HDFC Bank (combined) $=$ NOPAT $_{\text {combined- }}\left(\right.$ WACC $^{*}$ MV $\left._{\text {combined }}\right)$

EVA $_{\text {combined }}=\$ 1.083 \mathrm{Bn}-(0.06076 * \$ 30.9 \mathrm{Bn})=\$ 1.083 \mathrm{Bn}-\$ 1.877 \mathrm{Bn}$

$\mathbf{E V A}_{\text {combined }}=-\$ 0.794 \mathrm{Bn}$

(b) Current Operation Value of HDFC Bank (combined $)=\left(\mathrm{EVA}_{\text {combined }} / \mathrm{c}\right)+\mathrm{Capital}_{\text {combined }}=-$ $\$ 0.794 \mathrm{Bn} / 0.06076+\$ 22.12 \mathrm{Bn}=-\$ 13.07 \mathrm{Bn}+\$ 22.12 \mathrm{Bn}=\$ 9.05 \mathrm{Bn}$

Applying, .. Equation B

Market Value $=$ Current Operation Value + PV of Expected EVA Improvement 
Market Value $=$ Capital $_{0}+$ Capitalized EVA $(E V A / c)+$ PV of Expected EVA Improv.

$\$ 30.9 \mathrm{Bn}=\$ 22.12 \mathrm{Bn}+(-\$ 13.07 \mathrm{Bn})+\mathrm{PV}$ of Expected EVA Improvement

Therefore, PV of Expected EVA Improvement $=\$ 21.85 \mathrm{Bn}$

So, Investors' expectations for return on total combined market value of $\$ 30.9 \mathrm{Bn}$ is ( $\$ 30.9 \mathrm{Bn} *$ $\mathrm{WACC}_{\text {combined }}$ ) or $\$ 1.877 \mathrm{Bn}$ out of which return on future growth value of HDFC Bank (combined) would be (PV of Expected EVA Improvement* $\mathrm{WACC}_{\text {combined }}$ ) i.e.

Return on HDFC Bank Combined FGV $=\$ 21.85 * 0.0676$ or $\$ 1.327 \mathrm{bn}$

With our assumtion of $\Delta \mathrm{FGV}=0$, to provide return of $\$ 1.327 \mathrm{Bn}$ or $\$ 1327$ million on HDFC Bank (combined) future growth value, the company need to acheive,

$\$ 1.327 \mathrm{Bn} / \$ 17.46=\$ 0.076 \mathrm{Bn}$ or $\$ 76 \mathrm{mn}$ of $\Delta \mathrm{EVA}$ improvement in perpetuity as each $\$ 1$ of EVA improvement contribute $\$ 17.46$ of value.

(using $\$ 1+\$ 1 / 0.06076=\$ 17.46-$ Equation $C$ )

The relevant extract from acquirer company's financial report has been reproduced below.

\section{Actual performance in relation to performance benchmark}

Table 2. Analysis on HDFC Bank (combined) on Proforma Base Figure

\begin{tabular}{|c|c|c|c|c|c|c|c|}
\hline S.No. & Year Ending March 31st & $\mathbf{2 0 0 7}$ & $\mathbf{2 0 0 8}$ & $\mathbf{2 0 0 9}$ & $\mathbf{2 0 1 0}$ & $\mathbf{2 0 1 1}$ & $\mathbf{2 0 1 2}$ \\
\hline 1. & Capital employed (average) & 22.12 & 33.15 & 38.53 & 47.47 & 53.52 & 56.77 \\
\hline 2. & Average debt/total capital (\%) & 0.93 & 0.91 & 0.92 & 0.90 & 0.90 & 0.90 \\
\hline 3. & Beta variant $(\beta)$ & 0.9917 & 1.0089 & 0.7978 & 0.8836 & 1.0916 & 0.5792 \\
\hline 4. & Risk free debt cost (\%) (Rf) & 7.8 & 7.6 & 7.6 & 7.2 & 7.9 & 8.4 \\
\hline 5. & Market premium (RM-Rf) & 9.3 & 13.2 & -44.5 & 74.8 & 4.2 & -17.3 \\
\hline 6. & Cost of Equity (\%) & 13.94 & 20.92 & -27.90 & 73.29 & 12.484 & -1.62 \\
\hline 7. & Cost of Debt (post-tax) (\%) & 4.9 & 5.54 & 4.78 & 4.65 & 6.07 & 6.42 \\
\hline 8. & Weighted Average Cost of Capital (WACC) (\%) & 6.076 & 6.2271 & 5.9366 & 6.1642 & 6.784 & 7.99 \\
\hline & Enterprise Value (EV) & & & & & \\
\hline & Market Value of Equity & 18.48 & 28.27 & 9.57 & 55.34 & 76.09 & -27.44 \\
\hline & Value of Debt & 36.68 & 30.15 & 33.63 & 40.66 & 50.76 & 55.08 \\
\hline 9. & Enterprise Value & 58.42 & 43.20 & 96.00 & 126.85 & 27.64 \\
\hline & Computation of Economic Value Added (EVA) & & & & & & \\
\hline & Average Capital Employed & 14.2 & 18.2 & 33.15 & 38.53 & 47.47 & 53.52 \\
\hline & NOPAT & 0.270 & 0.289 & 0.093 & 0.479 & 0.901 & 1.023 \\
\hline & WACC & 0.06076 & & & & & \\
\hline 10. & EVA & -0.593 & -0.817 & -1.921 & -1.862 & -1.983 & -2.23 \\
\hline 11. & Improvement in EVA & -0.224 & -1.104 & +0.059 & -0.121 & -0.247 \\
\hline 12. & EVA as per Performance Benchmark & & 0.076 & 0.076 & 0.076 & 0.076 & 0.076 \\
\hline 13. & Excess/negative EVA improvement against & & -0.300 & -1.18 & -0.017 & -0.1 .97 & -0.323 \\
\hline
\end{tabular}

*In July 2011 share of HDFC Bank were split in 5 (from Rs. 10/- to Rs 2/-) hence decrease in Market Value in 2012

\section{Finding}

When HDFC Bank acquired CBoP in 2008, India was on its war footing pace for growth and development. FDI inflows were high in the country with stable government at the centre and there was immense scope for expansion of financial and allied services. M\&A success depends not only in availability of scope but depends entirely on realization of synergy, management of scale of operations and accomplishment of competitive cost advantages.

The analysis shows HDFC Bank initially failed to achieve positive EVA and performance benchmark five years post merger. The possible reason could be regional diversity in operations of two entities and complexities involved in post merger integration. (See excerpt of SEC filing in US by HDFC bank in 2008 in the following page). This excerpt taken from the HDB 20-F" filed Sep 29, 2008.

\section{We may not realize possible benefits from the merger of Centurion Bank of Punjab Limited with us.}

On February 23, 2008, the Bank and Centurion Bank agreed in principle to the Merger (the "Proposed Merger") of the two banks. Subsequently, on obtaining requisite approvals, Centurion Bank of Punjab Ltd. 
Financial Markets, Institutions and Risks, Volume 3, Issue 1, 2019

ISSN (online) - 2521-1242 ISSN (print) - 2521-1250

merged with us effective May 23, 2008 as per the order of the Reserve Bank of India (RBI) dated May 20, 2008 .

While we believe that the benefits of the Proposed Merger will outweigh the overall costs of such a merger, as with any merger, the risk exists that the final outcome of the Proposed Merger may not produce the benefits we anticipate. The success of the Proposed Merger depends, in part, on our ability to realize potential synergies, growth opportunities and cost savings from combining the businesses of Centurion Bank with that of our own.

The realization of such benefits of the Proposed Merger may be blocked, delayed or reduced as a result of numerous factors, some of which will be outside our control. These factors include difficulties in integrating our existing operations with those of Centurion Bank, including personnel policies and procedures, overlapping branch networks, information systems and management and administrative functions, unforeseen contingent risks or latent liabilities that may only become apparent after the integration process is completed, loss of our and Centurion Bank's customers and loss of key personnel. The Bank will incur costs in connection with such integration process. There can be no assurance that these or other issues connected with the Proposed Merger will not emerge and have a material adverse effect on the Bank's financial condition and operations in the future.

\# Form 20-F is an SEC filing submitted to the US Securities and Exchange Commission used by certain foreign private issuers to provide information.20-F, 20-F/A Annual and transition report of foreign private issuers pursuant to sections 13 or $15(\mathrm{~d})$.

\section{Conclusion}

The study has concluded, after examining the operating performance of combined entity post acqusition using Economic Value Added concept, that M\&A indeed has effect on the operating performances of the entities involved. To add to this conclusion, one significant aspect that emerges while analyzing HDFC Bank and Centurion Bank of Punjab deal was that macro economic variables has played a significant contribution to the operational aspect of company post merger and acquisitions. Case studies of this deal in the window period of five years post M\&A pointed out struggle for striving for balance against macro variable threat by the combined entity post M\&A for sustainable growth. In HDFC Bank and Centurion Bank of Punjab dealbudding banking sector in India, post liberalization period of 1991-92, played a deterrent in achieving robust operating performance.

One of the major reasons for surge in the mergers and acquisitions activities is the liberalization of the Indian economy. Liberalization is forcing companies to enter into new businesses, consolidate in some and at the same time exit from others that are non-profitable and non-core competent. Keeping in mind the high failure rate of M\&A, the managers had always given due importance to pursue it in a planned manner. Corporations had known from past experience that it pays to develop a disciplined acquisition program consisted of managing the pre-acquisition phase, screening of right candidate among several remaining candidates, determining the mode of acquisition, negotiate and consummate the deal and finally managing post acquisition integration. This work emphasises on using Economic Value Added (EVA) as methodology to evaluate post acquisition operating performance of companies merged. EVA is the profit earned by the firm less cost of financing the firm's capital. The idea behind is that value is created when return on firm's economic capital employed is greater than the cost of that capital.

\section{References}

1. Bell, Elizabeth (2013). How to evaluate a merger using financial statements. Demand Media California, US.

2. Chandra, Prasanna. (2011). Financial management: Theory and practice. New Delhi, Tata McGraw Hill Publication.

3. Durity, Harry \& Goldman, Michael (2013). A Vision for $M \& A$ : Best practices for creating awinning acquisition strategy, The M\&A Advisor and Merrill Datasite.

4. Fairburn, James A., Kay, John A. (1989). Mergers and Merger Policy. Oxford University Press. $1^{\text {st }}$ edition, New York, US.

5. Fama, E. F. (1969). The adjustments of stock prices to new information. International Economic Review, $10(1), 1-21$. 
6. Gray, Andrew. (2003). Why do firms carry out mergers and acquisitions, and how can the difficulties involved be overcome? Retrieved from: www.andrewgray.com

7. Harris, R. \& Ravenscraft, D. (1991). The role of acquisitions in foreign direct investment: Evidence from the U.S. stock market. Journal of Finance, 46(3), 825-44.

8. Mergers and Acquisitions (2015). Retrieved from: www.en.wikipedia.org/wiki/Mergers_and_acquisitions.

9 Miller, Merton H. \& Modiglian, Franco (1961). Dividend policy, growth and the valuation of shares. Journal of Business, 344, 411-33.

10.Ramu, S. Shiva (1998). Corporate Growth through Mergers \& Acquisitions1998, SAGE Publications Pvt. Ltd; New Delhi 1 edition, India.

11 Ravenscraft, David J. \& Scherer, F.M. (1987). Mergers, sell-offs and economic efficiency. Washington, DC: The Brookings Institution.

11. Sharma, R.K. \& Gupta, Shashi K. (1997). Financial management theory and practice. Kalyani Publisher. India.

12.Sirower, Mark. L. (1997). The Synergy trap: How the company lose the acquisition game. New York: The Free Press.

13. Smith, Kenneth \& Lajoux, Alexandra Reed (2012). The Art of M\&A Strategy. New York: MacGraw Hill.

14. Weston, Fred J., Wang, K., Chung, S., \& Hong, Susan E. (1990). Mergers, Restructuring \& Corporate Control., London United Kingdom; Pearson Education Plc.

15. Maheshwari S.N. (2009). Financial Management: Theory \& Practice, Sultan Chand \& Sons; New Delhi. South Asian Journal Various Issues.

17. Michel Gravel, Business valuation method. Retrieved from: www. iMergeAdvisors.com

18.Venkiteswaran, N. (1997). Restructuring of Corporate India: The Emerging Scenario, Vikalpa, Volume 22 No.2, July- September, 3-13

19. Kazushi Kan\&Taro Ohno. (2012). Mergers of Banks from EVA standpoint Public plocy Review, Japan, Vol 8, November.

20. KPMG-BS (1998). Corporate India Confronts the Value Challenge, The Strategist Quarterly, Jan-March. 